\title{
Plasma-induced polymerization as a tool for surface functionalization of polymer scaffolds for bone tissue engineering: An in vitro study
}

\author{
Paula M. López-Pérez, Ricardo M.P. da Silva, Rui A. Sousa, Iva Pashkuleva *, Rui L. Reis \\ 3B's Research Group - Biomaterials, Biodegradables and Biomimetics, University of Minho, Headquarters of the European Institute of Excellence on Tissue \\ Engineering and Regenerative Medicine, AvePark, 4806-909 Taipas, Guimarães, Portugal \\ IBB - Institute for Biotechnology and Bioengineering, PT Government Associated Laboratory, Braga, Portugal
}

\section{A R T I C L E I N F O}

\section{Article history:}

Received 16 September 2009

Received in revised form 16 February 2010

Accepted 3 March 2010

Available online 10 March 2010

\section{Keywords:}

Surface modification

Plasma polymerization

Osteoblast

Scaffold

\begin{abstract}
A B S T R A C T
A commonly applied strategy in the field of tissue engineering (TE) is the use of temporary three-dimensional scaffolds for supporting and guiding tissue formation in various in vitro strategies and in vivo regeneration approaches. The interactions of these scaffolds with highly sensitive bioentities such as living cells and tissues primarily occur through the material surface. Hence, surface chemistry and topological features have principal roles in coordinating biological events at the molecular, cellular and tissue levels on timescales ranging from seconds to weeks. However, tailoring the surface properties of scaffolds with a complex shape and architecture remains a challenge in materials science. Commonly applied wet chemical treatments often involve the use of toxic solvents whose oddments in the construct could be fatal in the subsequent application. Aiming to shorten the culture time in vitro (i.e. prior the implantation of the construct), in this work we propose a modification of previously described bone TE scaffolds made from a blend of starch with polycaprolactone (SPCL). The modification method involves surface grafting of sulfonic or phosphonic groups via plasma-induced polymerization of vinyl sulfonic and vinyl phosphonic acid, respectively. We demonstrate herein that the presence of these anionic functional groups can modulate cell adhesion mediated through the adsorbed proteins (from the culture medium). Under the conditions studied, both vitronectin adsorption and osteoblast proliferation and viability increased in the order SPCL $\ll$ sulfonic-grafted SPCL $<$ phosphonic-grafted SPCL. The results revealed that plasmainduced polymerization is an excellent alternative route, when compared to the commonly used wet chemical treatments, for the surface functionalization of biodevices with complex shape and porosity.

(c) 2010 Acta Materialia Inc. Published by Elsevier Ltd. All rights reserved.
\end{abstract}

\section{Introduction}

Tissue engineering (TE) emerged as an interdisciplinary field confronting the transplantation crisis caused by the shortage of donor tissues and organs. Since its inception, scaffolds composed of synthetic and natural polymers have been key elements of different TE approaches [1]. The use of an appropriate template to provide physical support and a local environment for cells and hence to enable and facilitate tissue development is an essential issue for a successful regeneration strategy. Nowadays, it is well accepted [2-4] that the ideal scaffold for bone TE must possess adequate porosity, resulting in an interconnected and permeable structure that allows the ingress of nutrients and cells. It is also believed that proper mechanical and physical properties, controlled

\footnotetext{
* Corresponding author at: 3B's Research Group - Biomaterials, Biodegradables and Biomimetics, University of Minho Headquarters of the European Institute of Excellence on Tissue Engineering and Regenerative Medicine, AvePark, 4806-909 Taipas, Guimarães, Portugal. Tel.: +351 253510907.

E-mail address: pashkuleva@dep.uminho.pt (I. Pashkuleva).
}

biodegradability, biocompatibility and the ability to promote cellular interactions and tissue development are other main requirements for TE scaffolds [2,5-8]. Last but not least, cells and surrounding tissues interact with any external devise primarily through the surface and therefore properties such as surface chemistry and topography are also key determinants in material-bioentity interactions.

Starch-based polymers have been studied as valuable materials for several biomedical applications [4,9]. Their biocompatibility and non-cytotoxicity have been confirmed by both in vitro [4,1012] and in vivo [13] assays. In this work, we have chosen fiber mesh scaffolds made from a blend of starch and $\varepsilon$-polycaprolactone (SPCL) which have been already proposed for bone tissue engineering $[4,8,10,11]$. Previous works have targeted their optimization in terms of degradability [7-9], porosity [4] and mechanical properties $[9,14]$, but few studies have focused on their surface properties [15] and the possibility of improving them [12,16]. Herein, we propose plasma-induced polymerization as a way to render an appropriate surface for enhancing cell adhesion and speeding up cell proliferation, which will shorten the culture time 
in vitro, i.e. prior to implantation. We have previously demonstrated $[17,18]$ that this method is a very effective way for grafting of vinyl polymers on regular two-dimensional (2-D) structures without modifying the bulk properties of the material. In this study, we report the effectiveness of this method for the functionalization of 3-D structures with a complex shape and with the negatively charged sulfonic and phosphonic groups, and the influence of these groups on osteoblast cell behavior in vitro.

Anionic scaffolds have been investigated because of their ability to facilitate morphogenetic processes for tissue engineering substitutes $[19,20]$. For example, the negative charge of glucosaminoglycans (GAGs) is associated with their bioactivity. GAGs interact with the positively charged amino groups of extracellular proteins and these interactions determine cell-matrix adhesion. Recent studies with sulfate-derived materials indicate enhanced adhesion and proliferation of osteoblast-like cells as a result of the presence of the sulfate groups $[17,21]$. On the other hand, the introduction of phosphate groups has been also proposed as an attractive modification strategy in targeting bone tissue engineering applications $[18,22-24]$. The rationale for the use of this functionality stems from mimicry of bone-promoting proteins and the mineral-bone matrix. Phosphate-rich proteins are known to initiate nucleation of mineralized bone and tooth matrix. It is also reported that many bone-promoting proteins naturally interact with acidic polymers [25].

\section{Materials and methods}

\subsection{Materials}

In this work, we used a commercially available blend (Mater-Bi ZI01U, Novamont, Italy) of thermoplastic starch and poly( $\varepsilon$-polycaprolactone) (SPCL, 30/70 wt.\%) [26,27]. The material was supplied in a granular form and processed by melt spun into fibers. Vinyl phosphonic acid (VPA) and vinyl sulfonic acid (VSA) were purchased from Sigma-Aldrich and used without further purification.

\subsection{SPCL mesh production and modification}

Fibers of SPCL were produced by melt spinning using a modular co-rotating twin screw extruder (Leistritz AG-LSM 36/25D, Germany) at a screw speed of $3 \mathrm{rpm}$ and with a temperature profile in the barrel (from the feed zone to the die zone) of between 60 and $130{ }^{\circ} \mathrm{C}$. The average output rate was $0.3 \mathrm{~kg} \mathrm{~h}^{-1}$. Upon extrusion through the die, the filament was spun in two consecutive steps to a final draw ratio of approximately 1:100. The cooling of the filament was performed in air (average temperature of $17^{\circ} \mathrm{C}$ ). Melt-spun fibers presented a diameter in the $105-345 \mu \mathrm{m}$ range, with a mean fiber diameter of $213 \pm 50 \mu \mathrm{m}$. The fibers were cut into $0.5 \mathrm{~cm}$ lengths and used in the production of fiber mesh scaffolds by a custom-designed mould. Fiber bundles were randomly displaced into the mould cavities and subjected to thermal treatment at $60{ }^{\circ} \mathrm{C}$ for 30 min before predefined compression levels along the $Z$-axis were applied to ensure the bonding between neighboring fibers using a final compression ratio of $22 \%$. Upon demoulding, scaffolds with dimensions $2.2 \pm 0.2 \mathrm{~mm}$ thickness and $6 \mathrm{~mm}$ diameter were obtained. Their porosity was measured by micro-computed tomography and the obtained averaged value was $64.4 \pm 4.4 \%$ (Fig. 1 ).

SPCL meshes were further modified by plasma-induced polymerization. Scaffolds were placed in a radio frequency (13.56 MHz) plasma reactor (Plasma Prep5, Gala Instrument, Germany) and exposed to $\mathrm{O}_{2}$ plasma at $30 \mathrm{~W}$ of power for $15 \mathrm{~min}$. During the treatment the pressure inside the reactor was maintained below 20 Pa by adjusting the gas flow. The activated meshes with free radicals formed on the surface were subsequently immersed in a degassed solution of VPA (100 mM in 2-propanol) or VSA

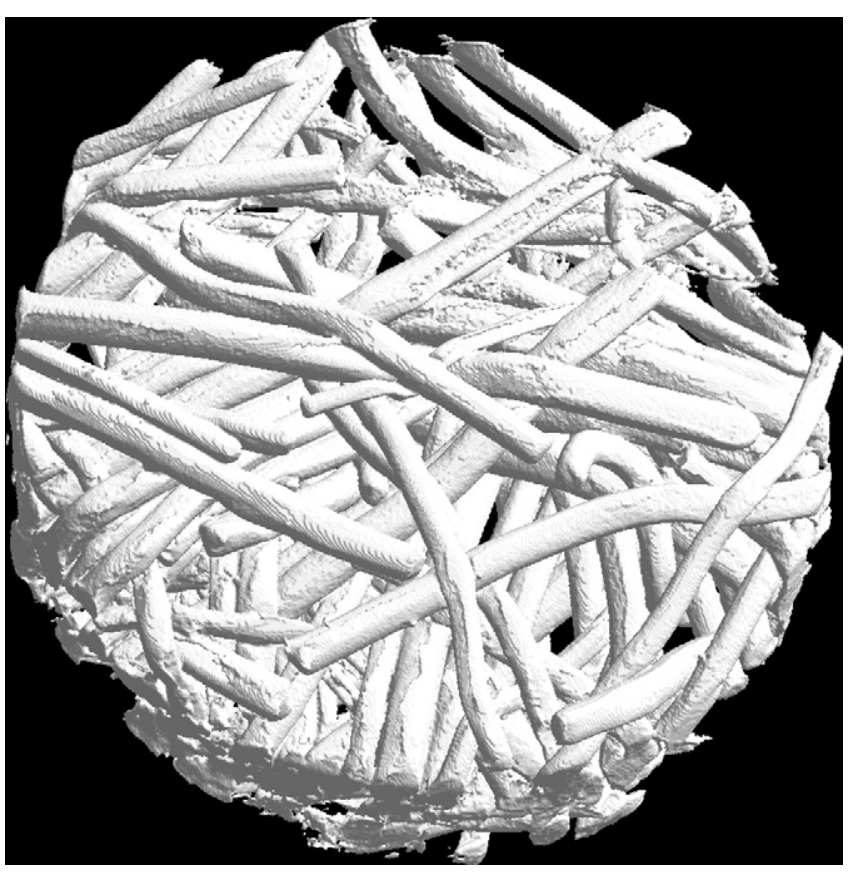

Fig. 1. Micro-computed tomography image from SPCL fiber mesh scaffold.

(10 vol.\% aqueous solution) at a ratio of $2 \mathrm{ml}$ per scaffold. The reaction was carried out at room temperature for $2 \mathrm{~h}$ under stirring. The scaffolds were washed thoroughly with the solvent used for the reaction in order to remove any unreacted monomer and finally the modified samples were dried at room temperature.

\subsection{Surface chemical composition}

Surface elemental analysis of untreated and modified samples was performed by X-ray photoelectron spectroscopy (XPS). The spectra were obtained using an ESCALAB 200A instrument from VG Scientific (UK) with PISCES software for data acquisition and analysis. The spectrophotometer was calibrated with reference to $\mathrm{Ag} 3 \mathrm{~d} 5 / 2$ (368.27 eV). Monochromatic Al Ka radiation ( $h v=1486.60 \mathrm{eV})$ operating at $15 \mathrm{kV}(300 \mathrm{~W})$ was used and the measurements were performed at a take-off angle of $90^{\circ}$ relative to the sample's surface in constant analyzer energy mode (CAE). Survey spectra were acquire using a pass energy of $50 \mathrm{eV}$ over a binding energy range of $0-1100 \mathrm{eV}$, and were used to calculate the elemental composition of the surfaces. High-resolution spectra for different regions were obtained using a pass energy of $20 \mathrm{eV}$. The peaks were fitted using the least-squares peak analysis software XPSPEAK version 4.1 and the Gaussian/Lorenzian sum function. Background counts were subtracted using a linear baseline and the sample charging was corrected assigning a binding energy of $285.0 \mathrm{eV}$ to the saturated hydrocarbons $\mathrm{C} 1 \mathrm{~s}$ peak.

\subsection{Surface topography}

The topography of the samples was characterized by optical profiler analysis using a Wyko-NT 1100 interferometric profiler (Veeco) operating in vertical scanning interferometry mode. The images were processed and analyzed with the analytical software package WycoVision ${ }^{\circledR} 32$.

\subsection{Protein adsorption}

The effect of the surface treatments on protein adsorption was analyzed by fluorescent immunolabeling. Two adhesion proteins 
were studied: fibronectin ( $\mathrm{Fn}$ ), because it is commonly used in a standard procedures applied to improve adhesion of cells; and vitronectin $(\mathrm{Vn})$, because of its influence on cell spreading and migration. Unmodified and grafted SPCL scaffolds were incubated for $1 \mathrm{~h}$ under the same conditions as used for in vitro cell culture, i.e. in a complex protein solution composed of 10 vol.\% heat-inactivated fetal bovine serum (FBS; Biochrom AG, Germany) in Dulbecco's modified Eagle's medium (DMEM; Sigma-Aldrich, Inc., USA). Samples immersed in phosphate-buffered saline solution (PBS; Sigma-Aldrich, Inc., USA) were used as blanks. After incubation, the samples were washed with PBS and incubated at room temperature for a further for $1 \mathrm{~h}$ with primary antibody mouse anti-cow Vn (Santa Cruz, USA) or mouse anti-cow Fn (Santa Cruz, USA). Both primary antibodies were diluted at a ratio of 1:50 (v/ v) in $1 \%(\mathrm{w} / \mathrm{v})$ bovine serum albumin (Sigma-Aldrich, USA) solution in PBS. All samples were again washed and incubated for $1 \mathrm{~h}$ at room temperature, this time with goat anti-mouse Alexa Fluor $488 \operatorname{IgG}(\mathrm{H}+\mathrm{L})$ secondary antibody (Invitrogen, USA). Labeled samples were analyzed by an Olympus IX81 confocal laser scanning microscope (CLSM).

\subsection{Cell culture conditions and seeding}

A human osteosarcoma cell line (SaOs-2), an immortalized cell line with an osteoblastic phenotype, was obtained from the European Collection of Cell Cultures (ECACC, UK) and was used in the cell culture studies. The cells were cultured in DMEM supplemented with $10,000 \mathrm{U} \mathrm{ml}^{-1}$ penicillin-G sodium, $10,000 \mu \mathrm{g} \mathrm{ml}^{-1}$ streptomycin sulfate and $25 \mu \mathrm{g} \mathrm{ml}^{-1}$ amphotericin B in $0.85 \%$ saline (Gibco, Invitrogen Corporation, UK) and 10\% FBS in a humidified atmosphere with $5 \% \mathrm{CO}_{2}$. A suspension of $2 \times 10^{5}$ cells was added to each scaffold. The scaffolds were incubated for 3, 7 and 14 days under standard culture conditions $\left(37^{\circ} \mathrm{C}, 5 \% \mathrm{CO}_{2}\right.$, humidified atmosphere).

The morphology of SaOs-2 cells was observed by scanning electron microscopy (S360, Leica Cambridge, UK). Cells were fixed using 2.5 vol.\% glutaraldehyde (Sigma, USA) solution in PBS. Prior to the analysis, the samples were dehydrated by graded ethanol solutions.

Cell viability was analyzed by MTS 3-(4,5-dimethylthiazol-2yl)-5-(3-carboxymethoxyphenyl)-2-(4-sulfophenyl)-2H-tetrazolium) assay. The cultured materials were incubated $\left(3 \mathrm{~h}, 37^{\circ} \mathrm{C}\right.$, humidified atmosphere of $5 \% \mathrm{CO}_{2}$ ) with $500 \mu \mathrm{l}$ of MTS solution in DMEM culture medium without phenol red (Sigma-Aldrich, Inc., USA). Optical density was read with a microplate reader (Bio-Tek, USA) at $490 \mathrm{~nm}$.

DNA quantification was used to evaluate cell proliferation. Cells were lysed by osmotic and thermal shock and the supernatant obtained was used for DNA analysis. The DNA content along the time of culture was determined using a PicoGreen dsDNA kit (MolecularProbes) and the fluorescence was read $(485 \mathrm{~nm} / 528 \mathrm{~nm}$ of excitation/emission) using a microplate reader. The amounts of DNA were calculated from a standard curve.

Triplicates were analyzed at each time point for both assays (MTS and DNA). Statistical analysis was performed and the data are reported as mean \pm standard deviation. An analysis of variance (ANOVA) test for independent samples was performed and the differences were considered statistically significant if $p<0.05$.

\section{Results and discussion}

The surface design of biomedical devices applied in direct contact with the body is crucial for their acceptance by or rejection from the surrounding tissues. The modification of the surface chemistry and/or topography is a way to improve the biological performance of a biomaterial without changing its bulk properties. One of the most versatile and effective tools to tailor surface chemistry and properties of solids is polymer grafting. In contrast to physical coating, grafting has several advantages, such as the covalent attachment of graft chains onto a polymer surface which avoids their delamination and assures the long-term stability of the introduced functionalities. Several approaches have been proposed for surface grafting on 2-D structures, but not all of them are viable for complex 3-D architectures. As an example, plasma surface treatment can be applied for 3-D samples whose holes/ trenches are wider than the mean free path of the electrons and the Debye length because in this case the discharge which generated the active species can be sustained [28]. However, in a number of applications the dimensions of the structures can be smaller. Poll et al. [29] reported that oxygen plasma treatment of stacked textile sheets (with the distance between fibers in the range of 0.1-1 $\mathrm{mm}$ ) for times longer than $8 \mathrm{~min}$ can penetrate four fabric sheets. A similar experiment was carried out by Mukhopadhyay et al. [30] for paper sheets but with flourohydrocarbon plasma. They found that up to three sheets (each with thickness of $0.15 \mathrm{~mm}$ ) could be fluorinated by this treatment. Hollander [28] investigated the penetration of oxygen plasma in cylinders made of sintered polyethylene. He reported that samples with large pores $(80 \mu \mathrm{m})$ are readily penetrated $(5 \mathrm{~mm}$ in $60 \mathrm{~s})$ but that there is a limit for samples with smaller pores; objects with a pore size of $7 \mu \mathrm{m}$ can be penetrated to about $1.2 \mathrm{~mm}$. Based on these previous findings, in this study we chose highly porous and interconnected SPCL fiber mesh scaffolds (Fig. 1) with a thickness of about $2.2 \mathrm{~mm}$ ( $1.1 \mathrm{~mm}$ from the surface to the middle of the sample) to check out the applicability of plasma-induced polymerization for the grafting of phosphonic and sulfonic groups.

\subsection{Surface chemistry}

The success of the applied treatment was primarily checked by surface chemical analysis. A comparison of several surface characterization techniques for the analysis of similarly treated surfaces has demonstrated [17,31] that Fourier-transformed infrared spectroscopy with attenuated total reflectance is not sensitive enough to capture the introduced changes; the penetration of the infrared beam is about $1-5 \mu \mathrm{m}$. On the other hand, with XPS analysis, valuable information about the elemental composition and chemistry can be obtained at the surface level of the sample within a depth of $10-250 \AA$. Hence, XPS survey spectra were used to assess the surface elemental composition (at.\%) of untreated and modified SPCL scaffolds. Two main elements, $\mathrm{C}$ and $\mathrm{O}$, were present on the surface of untreated samples. The ratio between them was found to be similar to the theoretically calculated one for PCL (Table 1). This result indicates that the synthetic component is predominant on the surface of the sample, which is in agreement with previously reported results for SPCL materials [12,15]. Plasma-induced polymerization resulted in a higher oxygen content. Additionally, new peaks appear in the spectrum of the VPA-grafted sample corresponding to $\mathrm{P} 2 p(128.5 \mathrm{eV})$ and $\mathrm{P} 2 s(185.5 \mathrm{eV})$, confirming the introduction of phosphonic groups. We calculated the presence of phosphorous on the surface from the P $2 p$ transition and a concentration of 4.6 at.\% was found (Table 1). The presence of a sulfur peak (0.2 at.\%) in the XPS spectrum of the sample treated with VSA confirms the success of the grafting process with this monomer, albeit with a lower efficiency than the VPA grafting. Some impurities ( $\mathrm{Si}, \mathrm{N}, \mathrm{Na}, \mathrm{Sn}$ and $\mathrm{Cu}$ ) appear in the surface spectra of some samples, usually at very low concentration, and were excluded from the calculations of the elemental analysis (at.\%) shown in Table 1.

$\mathrm{C} 1 s, \mathrm{O} 1 s, \mathrm{P} 2 p$ and S $2 p$ core level spectra of untreated and grafted materials were analyzed in order to obtain additional details about the surface chemical composition. Fig. 2a shows the binding en- 
Table 1

Elemental composition of untreated and modified SPCL fiber meshes determined by XPS.

\begin{tabular}{llllll}
\hline Material & C1s (at.\%) & O1s (at.\%) & P2p (at.\%) & S2p (at.\%) & C:O ratio \\
\hline Starch (theoretical) & 50.0 & 50.0 & - & - & 1.0 \\
PCL (theoretical) & 75.0 & 25.0 & - & - & 3.0 \\
SPCL (theoretical) & 67.4 & 32.6 & - & - & 2.1 \\
SPCL meshes & 75.1 & 24.9 & - & - & 3.0 \\
VSA-grafted SPCL & 67.8 & 32.0 & - & 0.2 & 2.1 \\
VPA-grafted SPCL & 51.1 & 44.3 & 4.6 & - & 1.1 \\
\hline
\end{tabular}

\section{C1s}
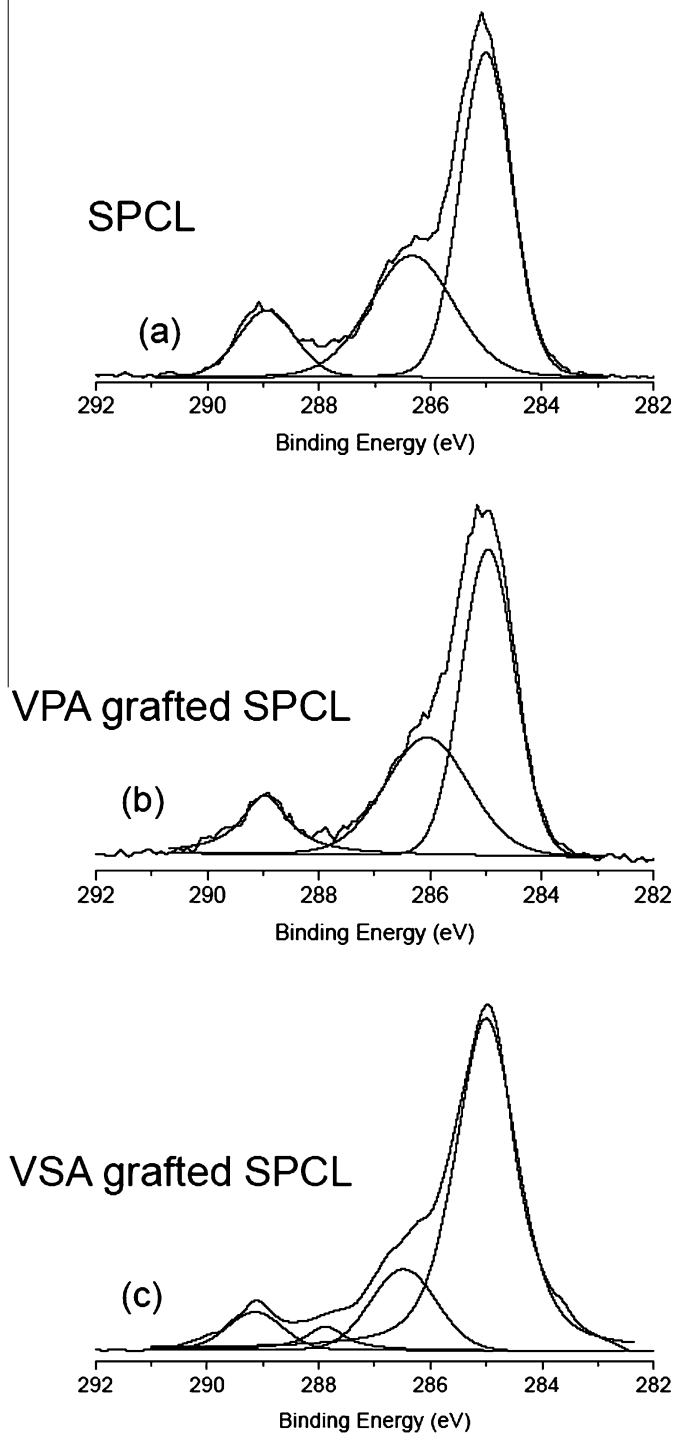

ergy region corresponding to the $\mathrm{C} 1 \mathrm{~s}$ peak $(279.8-291.9 \mathrm{eV})$ for the SPCL sample. The peak-fitting was performed taking into consideration the chemical structures of both PCL and starch (Fig. 3). The peak at $285.0 \mathrm{eV}$ was assigned to the $\mathrm{C}-\mathrm{H} / \mathrm{C}-\mathrm{C}$ chemical bonds of the starch backbone and the $\mathrm{C}-\mathrm{C}$ chain from PCL. The signal centered at $286.3 \mathrm{eV}$ corresponds to the hydroxyl-bonded carbons $(\mathrm{C}-\mathrm{OH})$ from starch and the ester-bonded carbons $(\mathrm{C}-\mathrm{O})$ from PCL. The peak observed at $288.9 \mathrm{eV}$ was assigned to the $\mathrm{O}-\mathrm{C}-\mathrm{O}$ bonds from starch and the $\mathrm{C}=\mathrm{O}$ bond from the synthetic component [32]. The C1s spectrum of VPA-grafted samples (Fig. 2b) did (d)

O1s

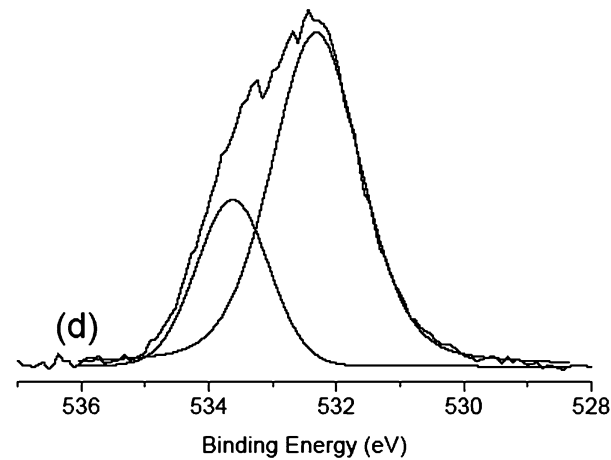

(e)
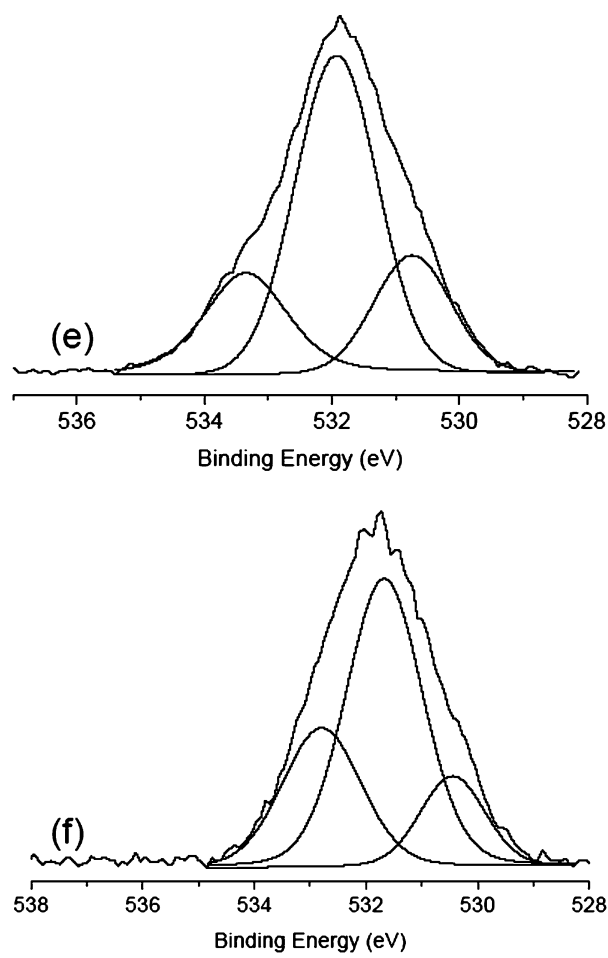

Fig. 2. XPS core level spectra of untreated and grafted samples in the C1s (left) and 01s (right) regions.

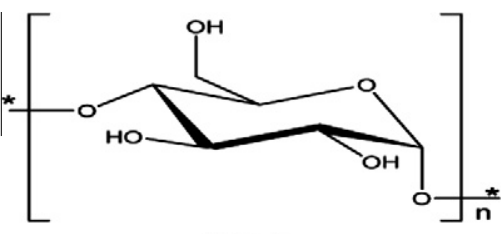

Starch<smiles>CCC(=O)CCCCCOC(C)(C)C</smiles>

poly ( $\varepsilon$-caprolactone)

Fig. 3. Chemical structures of the components of the blend. 
not reveal significant changes when compared with untreated SPCL scaffolds. The expected binding energy of C-P is around 286$286.4 \mathrm{eV}[33,34]$ and therefore the $\mathrm{C} 1 \mathrm{~s}$ peak corresponding to $\mathrm{C}-$ $\mathrm{PO}_{3}$ is probably overlapped by the $\mathrm{C}-\mathrm{OH} / \mathrm{C}-\mathrm{O}$ peak. For VSA- grafted samples (Fig. 2c), a new peak was detected at $287.9 \mathrm{eV}$ and was assigned to $\mathrm{C}-\mathrm{S}$ bonds from sulfonic acid. To our knowledge only a few works have focused on the chemical shift of $\mathrm{C}-\mathrm{S}$ and there is not agreement in the reported values [35-37]. Two
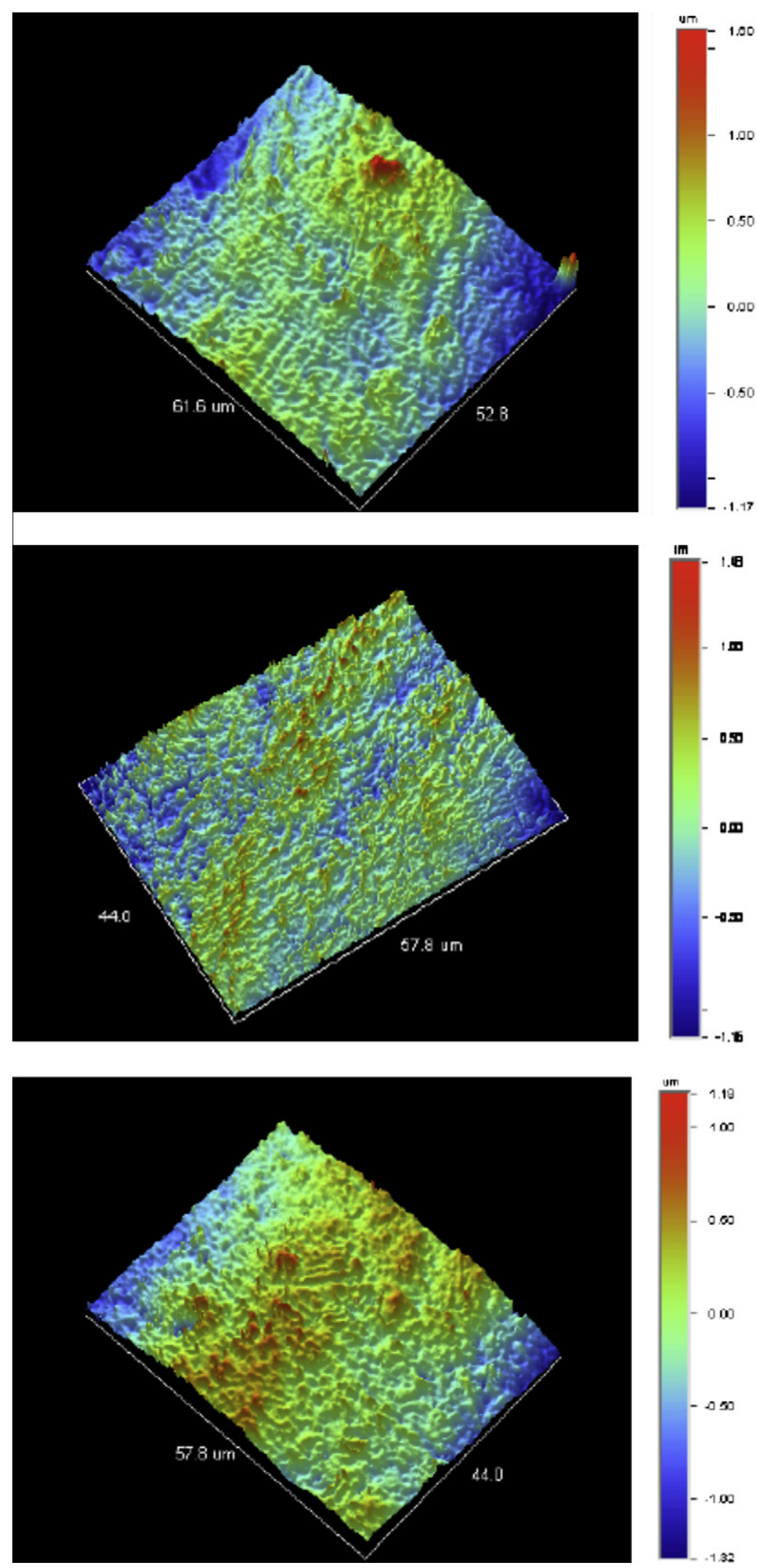

Fig. 4. Optical profile images. From top to bottom: untreated SPCL, VSA-grafted and VPA-grafted scaffolds. 
Table 2

Values for the roughness, calculated from the optical profiler images (107x magnification)

\begin{tabular}{llll}
\hline & SPCL & VSA-grafted SPCL & VPA-grafted SPCL \\
\hline$R_{\mathrm{a}}(\mathrm{nm})$ & $219.0 \pm 22.7$ & $245.1 \pm 16.0$ & $255.1 \pm 14.0$ \\
$R_{\mathrm{q}}(\mathrm{nm})$ & $283.7 \pm 34.6$ & $308.3 \pm 11.7$ & $335.6 \pm 20.5$ \\
\hline
\end{tabular}

peaks were identified in the high-resolution $01 s$ spectrum of SPCL scaffolds (Fig. 2d). The peak at $532.3 \mathrm{eV}$ was assigned to $\mathrm{C}=\mathrm{O}$ bonds from PCL $[33,37]$ and the peak at $533.6 \mathrm{eV}$ to $\mathrm{C}-\mathrm{OH} / \mathrm{O}-\mathrm{C}-\mathrm{O}$ from starch and $\mathrm{C}-\mathrm{O}-\mathrm{C}$ from both synthetic and natural components of the blend [37]. After VPA grafting (Fig. 2e), additional peak at $531.0 \mathrm{eV}$ appears in the $01 \mathrm{~s}$ spectrum which was attributed to the $\mathrm{P}=\mathrm{O}$ group. The second peak at $532.0 \mathrm{eV}$ was assigned to the $\mathrm{C}=\mathrm{O}$ and the last peak at $533.4 \mathrm{eV}$ corresponds to the $\mathrm{C}-\mathrm{O} / \mathrm{C}-\mathrm{OH} /$ $\mathrm{C}-\mathrm{O}-\mathrm{C}$ and $\mathrm{P}-\mathrm{OH}$ groups, for which binding energies between 533.0 and $533.6 \mathrm{eV}$ have been reported $[33,34,38]$. The $01 \mathrm{~s}$ core level spectra of the VSA-grafted samples (Fig. 2f) showed a new additional peak compared to the untreated SPCL scaffolds. This peak is at $531.1 \mathrm{eV}$ and was assigned to $\mathrm{O}=\mathrm{S}$ bonds $[35,36]$. The P2 $p$ signal that appears in the spectrum of VPA-grafted fiber meshes is a nonresolved doublet with $2 p 1 / 2$ and $2 p 3 / 2$ core levels. The peak is at $133.6 \mathrm{eV}$ and presents a full width at half-maximum of $2.1 \mathrm{eV}$ $[33,38]$ (spectrum not shown).

\subsection{Surface topography}

When a polymer surface is treated by plasma, together with surface functionalization, surface degradation or etching may also occur [39]. Hence, chemical surface modification is usually associated with changes in the surface topography/morphology. Consequently, the protein and cell interactions with the material may also be modified. An optical profiler analysis was performed to evaluate the eventual topographical changes on the surface of the fibers as a result of the applied treatment. As can be seen in Fig. 4, no significant changes were detected on the fiber surfaces after the performed modification. Although the roughness calculated from $107 \times$ magnification images seems to increase in absolute value after the plasma treatment (Table 2), it should be noted that this tendency is not fully clear because of the difference in the roughness between fibers in the same scaffold.

\subsection{In vitro biological evaluation: protein adsorption and cell response}

When a biomaterial is brought into contact with a physiological milieu, it is very unlikely that cells will make direct contact with its surface. The very first event either in vivo or in vitro is the adsorption of protein from blood or serum on the material's surface [4042 ]. The surface properties set the characteristics of the adsorbed protein layer, and the nature of the established protein-surface interactions will modulate cell adhesion and consequently cell biochemical mechanisms via interactions with cell-surface molecules, such as integrins $[43,44]$. Fig. 5 demonstrates that Vn adsorbed on all (untreated and modified) SPCL scaffolds, whereas Fn was not detected on any of the materials studied. This result is not surprising as it agrees with previously reported data for SPCL materials showing predominant adsorption of Vn vs Fn from complex protein solutions $[12,41]$. In fact, Vn is present at a higher concentration than Fn in FBS [45]. FBS for cell culture is prepared by clotting at $4{ }^{\circ} \mathrm{C}$, which can lead to a considerable depletion of Fn but not of $\mathrm{Vn}$ [45]. Another process which is associated with the lower protein adsorption of Fn vs $\mathrm{Vn}$ is the so-called Vroman effect [46], which involves inhibition of Fn adsorption from serum by other proteins that have the ability of displacing it from the surface. This effect has been observed for Fn when serum with a concentration above $3 \%$ is used [47]. Because we were working with $10 \%$ FBS, the lack of Fn adsorption was thus an expectable result. On the other hand, under these conditions, Vn can be adsorbed from the medium (Fig. 5), and can therefore participate in the mediation of sub-
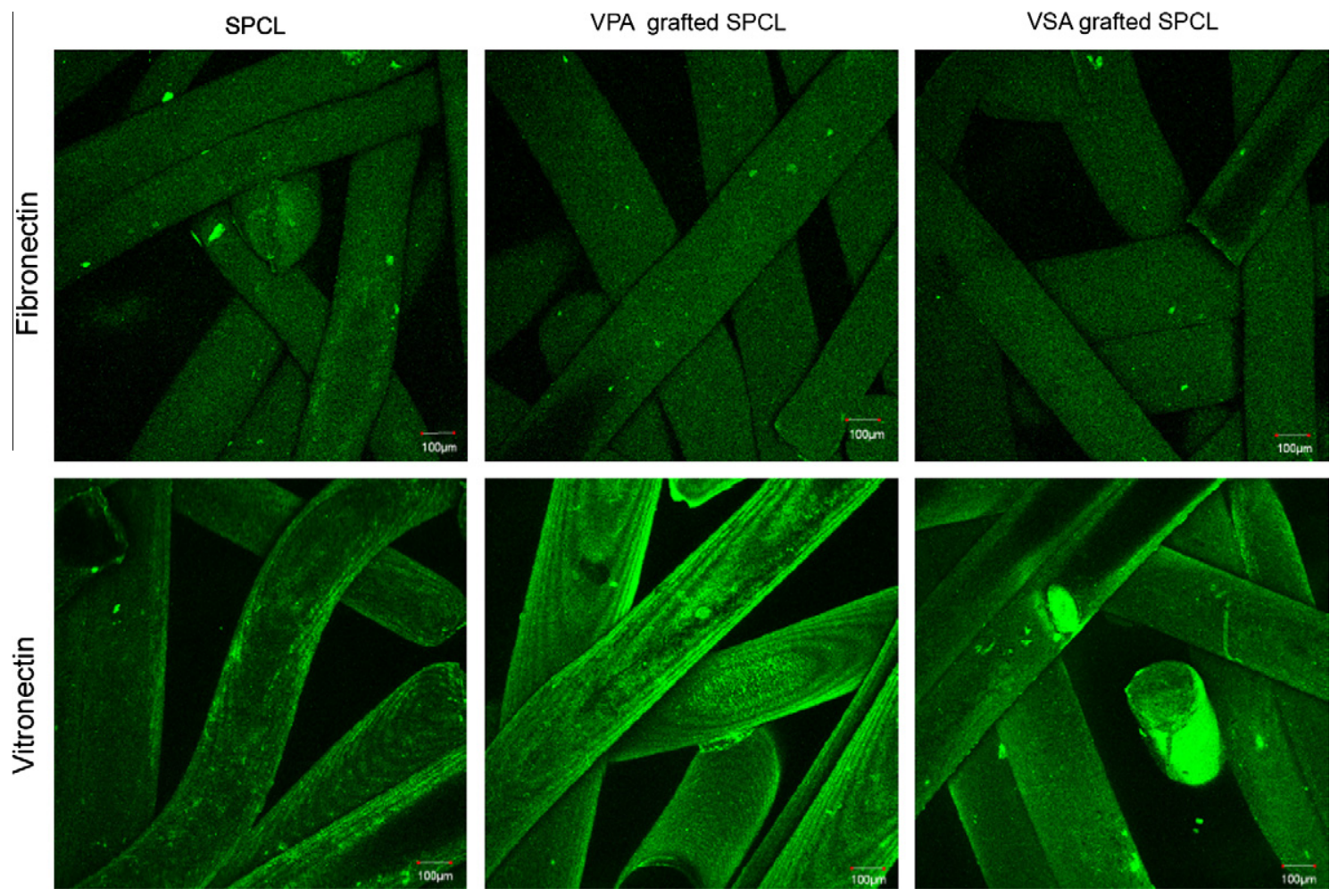

Fig. 5. Confocal laser scanning micrographs of non-modified and grafted scaffolds stained for Fn and Vn. 
sequent events, such as cell adhesion, spreading and growth [48]. The $\mathrm{Vn}$ adsorption profiles on untreated and modified materials showed that the fluorescence intensity for SPCL scaffolds increases after the modification with VSA and even more so after VPA grafting. These results indicate that the surface chemical composition significantly influences both the content of the adsorbed protein layer and the interactions between the material surface and the adsorbed proteins [40]. Vn plays an essential role in the attachment and spatial distribution of bone-derived cells $[49,50]$. Hence, it is expected that the observed difference in Vn adsorption on untreated and modified scaffolds will change the behavior of those cells. Therefore, we tested osteoblast-like cells cultured in direct contact with the studied materials. Osteoblast cells in vitro have been shown to depend primarily on the adsorbed Vn or Fn for initial adhesion and spreading on materials [51]. Therefore, the ability of materials to support cell adhesion and spreading is determined mainly by their ability to adsorb these proteins from serum in an active state.

Fig. 6 shows scanning electron micrographs of SaOs-2 seeded on the surfaces of modified and untreated samples after 3, 7 and 14 days of culture. After 3 days of culture cells were able to attach and spread on all the surfaces, showing the typical morphology of osteoblast cells with a polygonal shape. However, some differences were observed between the untreated SPCL and the grafted samples. While on modified scaffolds the cells were able to extend and bridge between fibers, on untreated samples these bridges were not observed. Prolongation of the culture periods to 1 and 2 weeks resulted in higher cell density, indicating the ability of SaOs-2 to proliferate on all of the materials. At 14 days of culture, SaOs-2 formed a complete monolayer covering all of the fibers, as well as some of the contact junctions between fibers. Not only can surface properties induce morphological changes, they can also influence the metabolic activity of the cells. MTS was used to evaluate the effect of the grafted functional groups on the cell viability

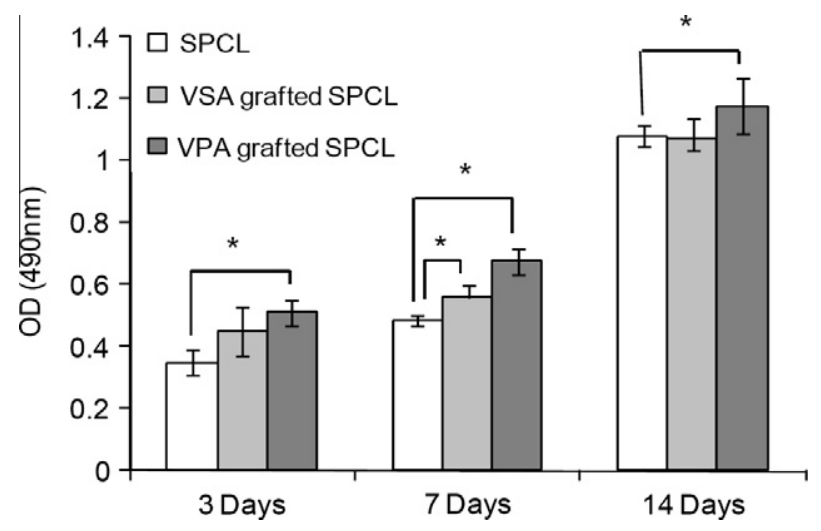

Fig. 7. Viability of SaOs-2, evaluated by MTS assay, cultured on untreated and grafted SPCL fiber meshes. *Significantly different (ANOVA, $p<0.05$ ).

at different time points. The MTS test is an indirect test that determines cell mitochondrial activity, which in turn can be related to the number of viable cells. For all the materials studied, an increasing number of viable cells were detected with prolonged culture time. These results show the ability of both unmodified and treated scaffolds to support cell proliferation. However, Fig. 7 demonstrates that the VPA grafting significantly increases the number of viable cells when compared with untreated SPCL scaffolds, and this tendency remained for the whole period studied. The presence of phosphate functional groups also increases the cell viability compared with sulfonic groups grafted under the same conditions. DNA quantification was used to obtain more accurate quantitative results and to determine the cell proliferation profiles (Fig. 8). DNA quantification confirmed the positive effect of the VSA and VPA grafting on the proliferation of SaOs-2. Once again, the same order was kept: SPCL $<$ VSA-grafted SPCL $<$ VPA-grafted SPCL.
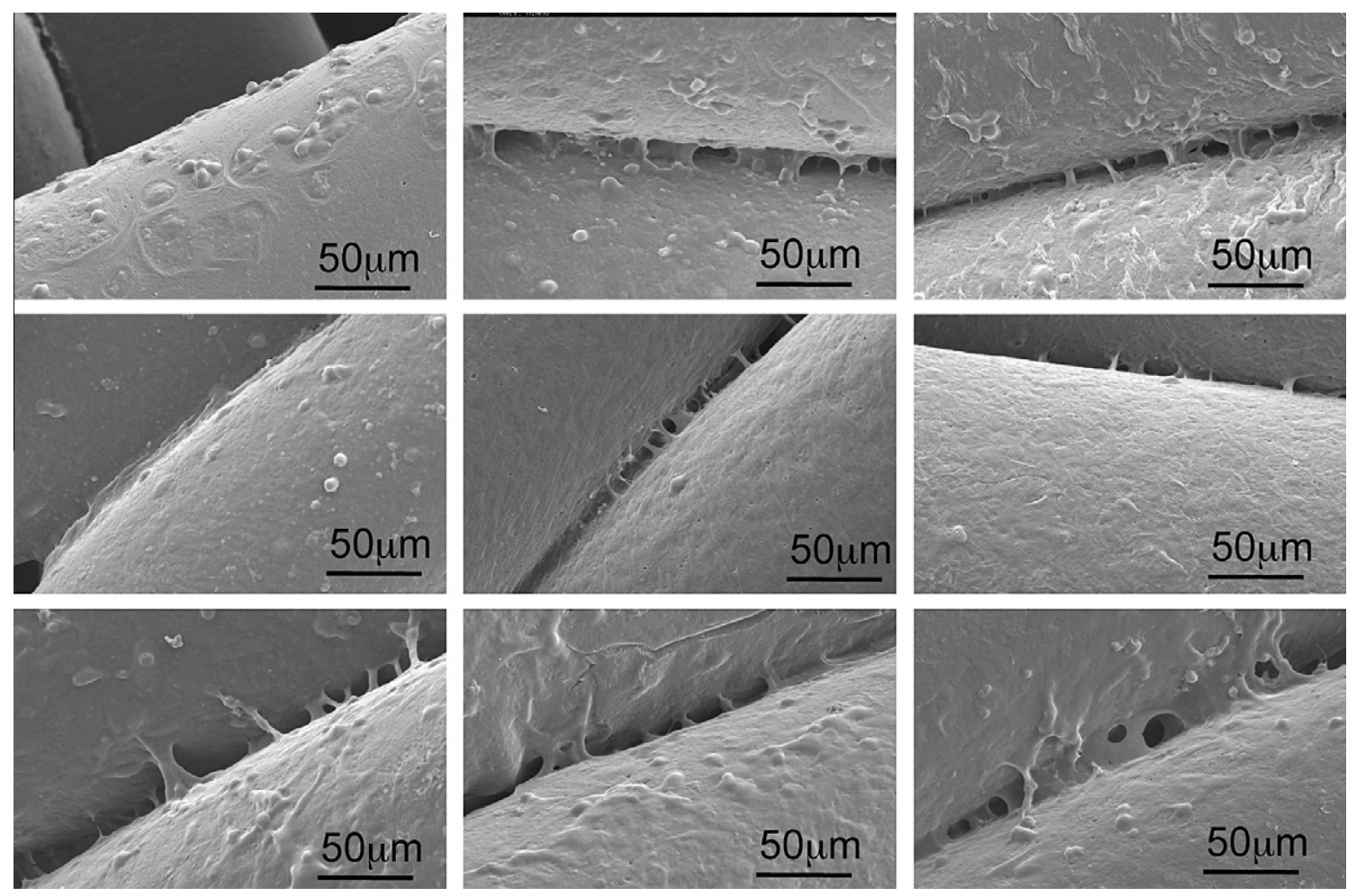

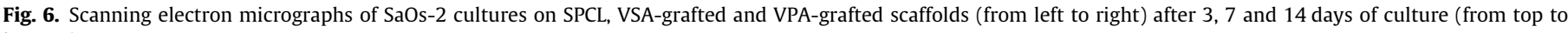
bottom). 


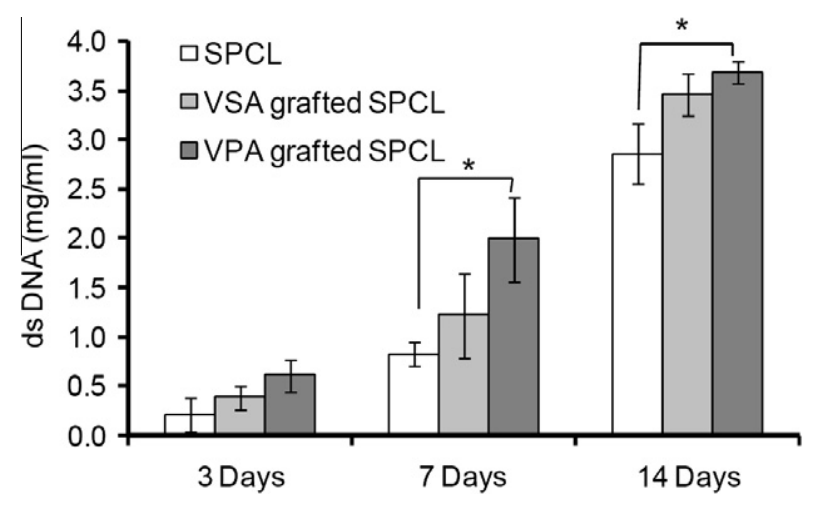

Fig. 8. DNA concentration corresponding to SaOs-2 cultured on non-modified and functionalized scaffolds. *Significantly different (ANOVA, $p<0.05$ ).

\section{Conclusions}

Plasma-induced polymerization is proposed herein as an effective method for 3-D porous scaffold functionalization. The results from the surface analyses confirmed that, using this method, we were successful in grafting sulfonic or phosphonic groups onto materials with a complex shape without changing the surface morphology and topography. Although this method can be extended to different materials and monomers, it should be noted that its efficiency is dependent on the monomer used: we found that the reaction was more efficient for VPA, with 4.6 at.\% $P$ measured on the surface, whereas only 0.2 at.\% $S$ was registered in the surface composition of VSA-grafted surfaces. The introduced functional groups modulate the protein adsorption from serum, as indicated by confocal microscopy analysis. In this study, we observed that Vn adsorption is favored on both modified samples compared with untreated SPCL scaffolds. Comparing the treated samples, the VPA-grafted samples presented greater quantities of adsorbed Vn compared with the VSA-grafted ones. However, this result could be related with the different efficiencies of the grafting process for the two monomers studied. Vn adsorption profiles were correlated with cell adhesion and proliferation studies; materials with greater Vn adsorption presented greater cell adhesion and proliferation. We further found that grafting of negatively charged units, such as sulfonic and phosphonic groups, induced remarkably different osteoblast-like cell (SaOs-2) responses in terms of adhesion and proliferation: under the conditions studied, VPA-grafted samples showed the greatest cell adhesion and proliferation.

Overall, the results from this study further testify to the potential of surface grafting of functional groups by plasma-induced polymerization in the context of bone tissue engineering.

\section{Acknowledgements}

The authors acknowledge funding from EU Marie Curie Actions, Alea Jacta Est (MEST-CT-2004-008104) and the Portuguese Foundation for Science and Technology (FCT) (SFRH/BPD/34545/2007). This work was carried out under the scope of the European NoE EXPERTISSUES (NMP3-CT-2004-500283). The authors also acknowledge Dr. M.I. Santos and C. Serra for their assistance on the CLSM and XPS experiments.

\section{Appendix A. Figures with essential colour discrimination}

Certain figures in this article, particularly Figures 4 and 5 are difficult to interpret in black and white. The full colour images can be found in the on-line version, at doi:10.1016/ j.actbio.2010.03.008).

\section{References}

[1] Vacanti JP, Langer R. Tissue engineering: the design and fabrication of living replacement devices for surgical reconstruction and transplantation. Lancet 1999;354:32-4.

[2] Liu X, Ma PX. Polymeric scaffolds for bone tissue engineering. Ann Biomed Eng 2004;32(3):477-86.

[3] Luo Y, Engelmayr G, Auguste DT, Ferreira LDS, Karp JM, Saigal R, et al. 25. Three-dimensional scaffolds. In: Lanza R, Langer R, Vacanti JP, editors. Principles of tissue engineering, 3rd ed. Amsterdam: Elsevier; 2007. p. 359-73.

[4] Gomes ME, Holtorf HL, Reis RL, Mikos AG. Influence of the porosity of starchbased fiber mesh scaffolds on the proliferation and osteogenic differentiation of bone marrow stromal cells cultured in a flow perfusion bioreactor. Tissue Eng 2006;12(4):801-9.

[5] Stevens B, Yang Y, Mohandas A, Stucker B, Nguyen KT. A review of materials, fabrication methods, and strategies used to enhance bone regeneration in engineered bone tissues. J Biomed Mater Res B Appl Biomater 2008;85(2):573-82.

[6] Tuzlakoglu K, Reis RL. Biodegradable polymeric fiber structures in tissue engineering. Tissue Eng Part B - Reviews 2009;15(1):17-27.

[7] Azevedo HS, Gama FM, Reis RL. In vitro assessment of the enzymatic degradation of several starch based biomaterials. Biomacromolecules 2003;4(6):1703-12.

[8] Martins AM, Pham QP, Malafaya PB, Sousa RA, Gomes ME, Raphael RM, et al. The role of lipase and alpha-amylase in the degradation of starch/poly(epsiloncaprolactone) fiber meshes and the osteogenic differentiation of cultured marrow stromal cells. Tissue Eng Part A 2009;15(2):295-305.

[9] Gomes ME, Azevedo HS, Moreira AR, Ella V, Kellomaki M, Reis RL. Starchpoly(epsilon-caprolactone) and starch-poly(lactic acid) fibre-mesh scaffolds for bone tissue engineering applications: structure, mechanical properties and degradation behaviour. J Tissue Eng Regenet Med 2008;2(5):243-52.

[10] Gomes ME, Sikavitsas VI, Behravesh E, Reis RL, Mikos AG. Effect of flow perfusion on the osteogenic differentiation of bone marrow stromal cells cultured on starch-based three-dimensional scaffolds. J Biomed Mater Res Part A 2003;67A(1):87-95.

[11] Santos MI, Fuchs S, Gomes ME, Unger RE, Reis RL, Kirkpatrick CJ. Response of micro- and macro-vascular endothelial cells to starch-based fiber meshes for bone tissue engineering. Biomaterials 2007;28(2):240-8.

[12] Santos MI, Pashkuleva I, Alves CM, Gomes ME, Fuchs S, Unger RE, et al. Surfacemodified 3D starch-based scaffold for improved endothelialization for bone tissue engineering. J Mater Chem 2009;19(24):4091-101.

[13] Marques AP, Reis RL, Hunt JA. An in vivo study of the host response to starchbased polymers and composites subcutaneously implanted in rats. Macromol Biosci 2005;5(8):775-85.

[14] Pavlov MP, Mano JF, Neves NM, Reis RL. Fibers and 3D mesh scaffolds from biodegradable starch-based blends: production and characterization. Macromol Biosci 2004;4(8):776-84.

[15] Pashkuleva I, Azevedo HS, Reis RL. Surface structural investigation of starchbased biomaterials. Macromol Biosci 2008;8(2):210-9.

[16] Pashkuleva I, Marques AP, Vaz F, Reis RL. Surface modification of starch based blends using potassium permanganate-nitric acid system and its effect on the adhesion and proliferation of osteoblast-like cells. J Mater Sci: Mater Med 2005;16:81-92.

[17] Lopez-Perez PM, Marques AP, da Silva RMP, Pashkuleva I, Reis RL. Effect of chitosan membrane surface modification via plasma induced polymerization on the adhesion of osteoblast-like cells. J Mater Chem 2007;17(38):4064-71.

[18] Lopez-Perez PM, da Silva RMP, Serra C, Pashkuleva I, Reis RL. Surface phosphorylation of chitosan significantly improves osteoblast cell viability, attachment and proliferation. J Mater Chem 2010;20(3):483-91.

[19] Moreira PL, An YH, Santos AR, Genari SC. In vitro analysis of anionic collagen scaffolds for bone repair. J Biomed Mater Res Part B Appl Biomater 2004;71B(2):229-37.

[20] Chen YM, Shiraishi N, Satokawa H, Kakugo A, Narita T, Gong JP, et al. Cultivation of endothelial cells on adhesive protein-free synthetic polymer gels. Biomaterials 2005;26(22):4588-96.

[21] Chaterji S, Gemeinhart RA. Enhanced osteoblast-like cell adhesion and proliferation using sulfonate-bearing polymeric scaffolds. J Biomed Mater Res Part A 2007;83A(4):990-8.

[22] Gemeinhart RA, Bare CM, Haasch RT, Gemeinhart EJ. Osteoblast-like cell attachment to and calcification of novel phosphonate-containing polymeric substrates. J Biomed Mater Res Part A 2006;78A(3):433-40.

[23] Tan J, Gemeinhart RA, Ma M, Saltzman WM. Improved cell adhesion and proliferation on synthetic phosphonic acid-containing hydrogels. Biomaterials 2005;26(17):3663-71.

[24] Viornery C, Guenther HL, Aronsson BO, Pechy P, Descouts P, Gratzel M. Osteoblast culture on polished titanium disks modified with phosphonic acids. J Biomed Mater Res 2002;62(1):149-55.

[25] He G, Dahl T, Veis A, George A. Nucleation of apatite crystals in vitro by selfassembled dentin matrix protein. Nat Mater 2003;2(8):552-8.

[26] Bastioli C, Belliotti V, Cella G, Del Guidice L, Montino S, Perego G, inventors; Novamont S.p.A., Novara, Italy, assignee. Biodegradable polymeric compositions comprising starch and a thermoplastic polymer, 14 May 1998.

[27] Bastioli C, Bellotti V, Del Tredici G, Lombi R, inventors; Novamont S.p.A., assignee. Biodegradable polymeric compositions based on starch and thermoplastic polymers. Italy Patent No. EP0539541B1, 9 July 1997. 
[28] Hollander A. Surface oxidation inside of macroscopic porous polymeric materials. Surf Coat Technol 2005;200:561-4.

[29] Poll HU, Schladitz U, Schreiter S. Penetration of plasma effects into textile structures. Surf Coat Technol 2001;142:489-93.

[30] Mukhopadhyay SM, Joshi P, Datta S, Macdaniel J. Plasma assisted surface coating of porous solids. Appl Surf Sci 2002;201(1-4):219-26.

[31] Gupta B, Plummer C, Bisson I, Frey P, Hilborn J. Plasma-induced graft polymerization of acrylic acid onto poly(ethylene terephthalate) films: characterization and human smooth muscle cell growth on grafted films. Biomaterials 2002;23(3):863-71.

[32] Clark DT, Cromarty BJ, Dilks A. ESCA applied to polymers. 24. Theoretical investigation of molecular core binding and relaxation energies in a series of oxygen-containing organic-molecules of interest in the study of surface oxidation of polymers. J Polym Sci Pol Chem 1978;16(12):3173-84.

[33] Adden N, Gamble LJ, Castner DG, Hoffmann A, Gross G, Menzel H. Phosphonic acid monolayers for binding of bioactive molecules to titanium surfaces. Langmuir 2006;22(19):8197-204.

[34] Viornery C, Chevolot Y, Leonard D, Aronsson BO, Pechy P, Mathieu HJ, et al. Surface modification of titanium with phosphonic acid to improve bone bonding: characterization by XPS and ToF-SIMS. Langmuir 2002;18(7):2582-9.

[35] Nasef MM, Saidi H. Surface studies of radiation grafted sulfonic acid membranes: XPS and SEM analysis. Appl Surf Sci 2006;252(8):3073-84.

[36] Ruangchuay L, Schwank J, Sirivat A. Surface degradation of alpha-naphthalene sulfonate-doped polypyrrole during XPS characterization. Appl Surf Sci 2002;199(1-4):128-37.

[37] Wagner CD, Naumkin AV, Kraut-Vass A, Allison JW, Powell CJ, Rumble JR, et al. NIST standard reference database. National Institute of Standards and Technology; 2003.

[38] Textor M, Ruiz L, Hofer R, Rossi A, Feldman K, Hahner G, et al. Structural chemistry of self-assembled monolayers of octadecylphosphoric acid on tantalum oxide surfaces. Langmuir 2000;16(7):3257-71.

[39] Chu PK, Chen JY, Wang LP, Huang N. Plasma-surface modification of biomaterials. Mater Sci Eng R 2002;36(5-6):143-206.
[40] Bale MD, Wohlfahrt LA, Mosher DF, Tomasini B, Sutton RC. Identification of vitronectin as a major plasma-protein adsorbed on polymer surfaces of different copolymer composition. Blood 1989;74(8):2698-706.

[41] Alves CM, Reis RL, Hunt JA. Preliminary study on human protein adsorption and leukocyte adhesion to starch-based biomaterials. J Mater Sci: Mater Med 2003;14(2):157-65.

[42] Mrksich M, Whitesides GM. Using self-assembled monolayers to understand the interactions of man-made surfaces with proteins and cells. Annu Rev Biophys Biochem 1996;25:55-78.

[43] Buck CA, Horwitz AF. Cell surface receptors for extracellular matrix molecules. Ann Rev Cell Biol 1987;3:179-205.

[44] Hynes RO. Integrins: bidirectional, allosteric signaling machines. Cell 2002;110:673-87.

[45] Hayman EG, Pierschbacher MD, Suzuki S, Ruoslahti E. Vitronectin - a major cell attachment-promoting protein in fetal bovine serum. Exp Cell Res 1985;160(2):245-58.

[46] Vroman L. Effect of adsorbed proteins on wettability of hydrophilic and hydrophobic solids. Nature 1962;196(4853):476.

[47] Knox P. Kinetics of cell spreading in the presence of different concentrations of serum or fibronectin-depleted serum. J Cell Sci 1984;71:51-9.

[48] Underwood PA, Bennett FA. A Comparison of the biological activities of the cell-adhesive proteins vitronectin and fibronectin. J Cell Sci 1989:93:641-9.

[49] McFarland CD, Mayer S, Scotchford C, Dalton BA, Steele JG, Downes S Attachment of cultured human bone cells to novel polymers. J Biomed Mater Res 1999;44(1):1-11.

[50] Thomas $\mathrm{CH}$, McFarland CD, Jenkins ML, Rezania A, Steele JG, Healy KE. The role of vitronectin in the attachment and spatial distribution of bone-derived cells on materials with patterned surface chemistry. J Biomed Mater Res 1997;37(1):81-93.

[51] Steele JG, McFarland C, Dalton BA, Johnson G, Evans MDM, Howlett CR, et al. Attachment of human bone cells to tissue culture polystyrene and to unmodified polystyrene - the effect of surface chemistry upon initial cell attachment. J Biomater Sci Polym Ed 1993;5(3):245-57. 